voir quandary in California; large-scale development projects, such as the Jonglei Canal in the Sudd, the Narmada project in India and the East Anatolia project in Turkey; land clearing along the Himalayan foothills and flooding in Bangladesh; land degradation in the Sahel and the Horn of Africa; and saline seeps in Australia and North America. Other important topics are treated only cursorily, such as desertification, and the greenhouse effect and its potential impact on natural ecosystems, agriculture and so on.

Unfortunately, the index is rather incomplete and does not direct the reader efficiently to the topics covered by the chapters. One example is the omission of the term 'ogallala aquifer', and this despite its explicit mention in the excellent chapter on the Great Plains region in the United States.

A final lacuna is the absence of a forward-looking assessment of possible ways in which policy-makers might take effective action. The final section provides theoretical insights that are interesting in themselves, but are scarcely sufficient to lay the necessary concrete foundations for practical strategies towards remedial action. Where might we go from here? How can human societies achieve a sustainable relationship with the Earth and its biota? These questions are left unanswered.

All the minor weaknesses notwithstanding, the very attempt by the editors and authors to encapsulate what geographers currently know and understand about so complex a subject is brave and admirable. In setting out what is known, the book, inter alia, exposes what is insufficiently known. The book is thus not only instructive but also challenging, making it a praiseworthy and most timely contribution.

Cynthia Rosenzweig is at Columbia University and the NASAGoddard Institute for Space Studies, 2880 Broadway, New York, New York 10025, USA; Daniel Hillel is in the Department of Plant, Soil and Environmental Sciences, University of Massachusetts, 11 Stockbridge Hall, Amherst, Massachusetts 01003, USA.

- Two other books relevant to the subject of this review were published last year. Global Environmental Change by A. M. Mannion is a broad undergraduate text examining how natural and cultural agents have transformed the Earth during the last three million years and how this knowledge might be used to plan for the future (Longman, $£ 14.99$ (pbk)). In Leaving Eden: To Protect and Manage the Earth, E. G. Nisbet discusses the chemical and physical processes that control our environment and the effects of human disruption of these systems, finishing with a review of ways in which the environment can be protected and restored (Cambridge University Press, £27.50, \$42.50 (hbk), £9.95, $\$ 14.95$ (pbk)).

\section{Bulldoggish persuasion}

\section{Colin Patterson}

Thomas Henry Huxley: Communicating for Science. By J. Vernon Jensen. University of Delaware Press and Associated University Presses: 1991. Pp. 253. \$38.50, £29.95.

RHETORIC - the art of persuasion in speech or writing - is not commonly seen as a necessary element in the education of scientists. In the United Kingdom, where there are no professors of rhetoric, it is evidently assumed that the art so necessary for politicians will be either inborn or acquired casually, perhaps by speaking at the Oxford Union or other debating societies. In North America, rhetoric can be part of the curriculum, and the author of this book teaches courses in it at the University of Minnesota. My only previous experience with a professor of rhetoric was through the hero of Robert M. Pirsig's Zen and the Art of Motorcycle Maintenance (1974), whose lectures led into his obsessive search for that slippery substance "quality". The same search must lie behind this book, a "rhetorical biography" of T. H. Huxley.

Huxley (1825-95) is best known today as a member of Darwin's coterie and as 'Darwin's bulldog', the man whose pugnacity did so much to advance the cause of evolution and materialism in the years following publication of On the Origin of Species. But with his lectures and essays, Huxley was also perhaps the first great publicist for science. Unlike Darwin, Huxley was not born into a moneyed dynasty and much of his early career in biology was spent seeking employment that would pay enough for him and his prospective wife to live on. His method was to make himself conspicuous, by publishing as much as he could and by attending and speaking at scientific meetings; the method is surely familiar to thousands of present-day graduates in biology. But by the time Huxley found a job, in 1854 , he was already a fellow and council member of the Royal Society of London, and had won a Royal Medal; these experiences are unfamiliar to more than a handful of present-day graduates in biology, and certainly to none in need of employment. Thus Huxley was in some ways part of our world, but in others part of a different one. What can we learn from this book that may help to reconcile the two, and teach today's aspirants something of quality?

The book is in no sense a connected biography, but a collection of essays linked by graceful bridging passages and closed by a polished summary and conclusion. The reason for this arrangement seems to be that Jensen has previously published the substance of most of the individual chapters as papers in journais. Three of the eight chapters are on "rhetorical milestones" in Huxley's career (his maiden public lecture, a Fridayevening discourse at the Royal Institution in 1852; his encounter with Bishop Wilberforce at the British Association meeting in 1860; and his lecture tour of the United States in 1876), and two chapters are on "private interpersonal communication in the life of the public rhetorician" - his three female confidantes early in his career, and the X Club, a group of nine like-minded scientists including Huxley, J. D. Hooker, Herbert Spencer, John Tyndall and John Lubbock, who dined together monthly from 1864 until age and mortality extinguished the club in the 1890s. That group had a remarkable influence on late Victorian science, providing three presidents of the Royal Society, five presidents of the British Association, and playing a large part in the foundation of Nature in 1869 . But that is history of science. The problem with discussing Huxley's rhetoric on occasions such as his first public address and the 1860 Oxford debate is that no one now knows just what was said. The book seems to me to come to life only after the US tour, of which there are ample records, and especially in the discussion of Huxley's style in his anticlerical sallies, late in life. Jensen argues persuasively that in those debates "Huxley was adopting a rhetorical stance more similar to theologians than he would probably care to acknowledge. Rhetorically he was a secular theologian."

One learns from the book that there are four ways of delivering a talk (impromptu, memorized, speaking from manuscript, extemporaneous; Huxley became a master of the fourth), and that there is no substitute for careful preparation. On writing, Huxley recommended Sheridan's remark: "Easy reading is damned hard writing." Hard work, many drafts and a well-stocked mind will all help, but in the end the style is the man: "Nothing comes of imitation but that every man's style should express his own individuality" was Huxley's recipe. In concentrating on the rhetorical aspect, Jensen says little of the scientific content of Huxley's lectures and writing. To learn, for example, why Huxley chose the topic "animal individuality" for his first public lecture, and how that talk initiated his lifelong feud with Richard Owen, one must look elsewhere.

Colin Patterson is at the British Museum (Natural History), Cromwell Road, London SW7 5BD, UK. 